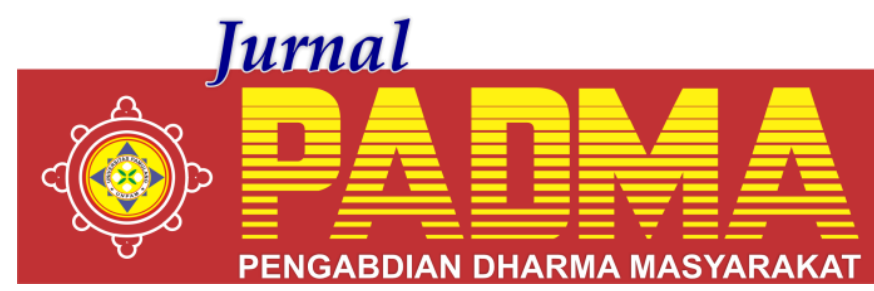

VOLUME 1, NOMOR 3, JULI 2021

\title{
MENINGKATKAN DAYA JUAL PRODUK MELALUI PEMASARAN ONLINE DI MASA PANDEMI PADA WPI (WIRAUSAHA PELAJAR INDONESIA) WILAYAH BOGOR
}

\author{
${ }^{1 *}$ Widhi Wicaksono, ${ }^{2}$ Suyatin, ${ }^{3}$ Panji Galih Kusumo Adie, ${ }^{4}$ Rachmawaty, ${ }^{5}$ Eko Cahyadi \\ Universitas Pamulang, Tangerang Selatan, Banten, Indonesia \\ *dosen01049@unpam.ac.id
}

\begin{abstract}
Abstrak
Generasi Muda adalah sebuah generasi unggul sebagai penerus generasi selanjutnya, walaupun saat ini masih di masa pandemi Covid-19, jiwa-jiwa muda yang memiliki bisnis atau UMKM (Usaha Mikro Kecil Menengah) harus terus berinovasi dan mengembangkan bisnisnya agar dapat berkembang dan mampu bertahan walaupun di masa pandemi saat ini WPI (Wirausaha Pelajar Indonesia) di berbagai cabang yang ada di Indonesia, seperti Bogor, Tangerang Selatan dan sebagainya, diharapkan mampu menambah jumlah UMKM di masing-masing kota, khususnya di Kota Bogor dan sekitarnya, namun sebagai wirausaha pemula yang tergabung dalam Wirausaha Pelajar Indonesia (WPI) perlu juga melakukan pemasaran melalui Online atau e-commerce yang dapat meningkatkan daya jual produk dan bersaing dengan usaha sejenis lainnya. Target dari PKM ini Bimbingan berupa arahan bagaimana menjadi para pelaku wirausaha yang berhasil dan wawasan mengenai bahan baku yang mudah didapat, cara terbaik pemasaran dan bagaimana produk laku serta bagaimana cara mendapatkan laba yang maksimal
\end{abstract}

Kata Kunci: Pemasaran Online, Masa Pandemi, Wirausaha Pelajar Indonesia, Bogor

\section{Abstract}

The Younger Generation is a superior generation as the next generation, although it is still in the covid-19 pandemic, young people who have businesses or MSMEs (Small and Medium Micro Enterprises) must continue to innovate and develop their businesses in order to grow and be able to survive even in the current pandemic WPI (Indonesian Student Entrepreneurship) in various branches in Indonesia, such as Bogor, South Tangerang and so on, it is expected to increase the number of MSMEs in each city, especially in the city of Bogor and its surroundings, but as a beginner entrepreneur who is a member of the Indonesian Student Entrepreneur (WPI) need to also do marketing through Online or e-commerce that can increase the selling power of products and compete with other similar businesses. The target of this PKM Guidance in the form of direction on how to become successful entrepreneurs and insights on raw materials that are easy to get, the best way of marketing and how products sell and how to get maximum profit.

Keywords: Online Marketing, Pandemic Period, Indonesian Student Entrepreneurship, Bogor

\section{PENDAHULUAN}

Generasi Muda adalah sebuah generasi unggul sebagai penerus generasi selanjutnya, walaupun saat ini masih di masa pandemi Covid-19, jiwa-jiwa muda yang memiliki bisnis atau UMKM (Usaha Mikro Kecil Menengah) harus terus berinovasi dan mengembangkan bisnisnya agar terus dapat berkembang dan mampu bertahan walaupun di masa pandemi saat ini. Salah satu mempertahankannya dapat dilakukan melalui strategi pemasaran secara Online seperti pemanfaatan media sosial di kalangan muda-mudi agar membuka peluang terjualnya produk atau jasa yang dipasarkan menjadi lebih luas dan terencana.
Dengan adanya WPI (Wirausaha Pelajar Indonesia) di berbagai cabang yang ada di Indonesia, seperti Bogor, Tangerang Selatan dan sebagainya, diharapkan mampu menambah jumlah UMKM di masing-masing kota, khususnya di Kota Bogor dan sekitarnya, karena semakin bertambahnya jumlah UMKM yang ada di Bogor, maka semakin bertambahnya pendapatan daerah melalui pembayaran pajak dari UMKM itu sendiri, sebagaimana untuk mengetahui tingkat kesejahteraan suatu daerah yaitu dari seberapa besar pendapatan regional perkapita penduduk, karena PDRB (Produk Domestik Regional Bruto) sebagai ukuran produktivitas mencerminkan seluruh nilai 
barang dan jasa yang dihasilkan oleh suatu wilayah dalam satu tahun.

Berdasarkan data BPS (Badan Pusat Statistik) kota Bogor menunjukkan bahwa Struktur perekonomian pada dasarnya menunjukkan besaran kontribusi masingmasing sektor ekonomi terhadap perekonomian suatu daerah. Jika kita meninjau PDRB dari sisi sektoral, pada tahun 2020 dengan bentuk presentase, maka lapangan usaha Reparasi Kendaraan memberikan kontribusi terbesar dalam pembentukan PDRB Kota Bogor tahun 2020 yaitu sebesar 20\%, kemudian diikuti oleh lapangan usaha Pengolahan sebesar 18\%, Transportasi dan Pergudangan 13\%, Konstruksi 12\%, dan Industri Lainnya sebagaimana data terlampir dalam diagram di bawah ini.

Produk Domestik Regional Bruto Kota Bogor Atas Dasar Harga Berlaku Menurut Lapangan Usaha (miliar rupiah), pada tahun 2020, sebagai berikut:

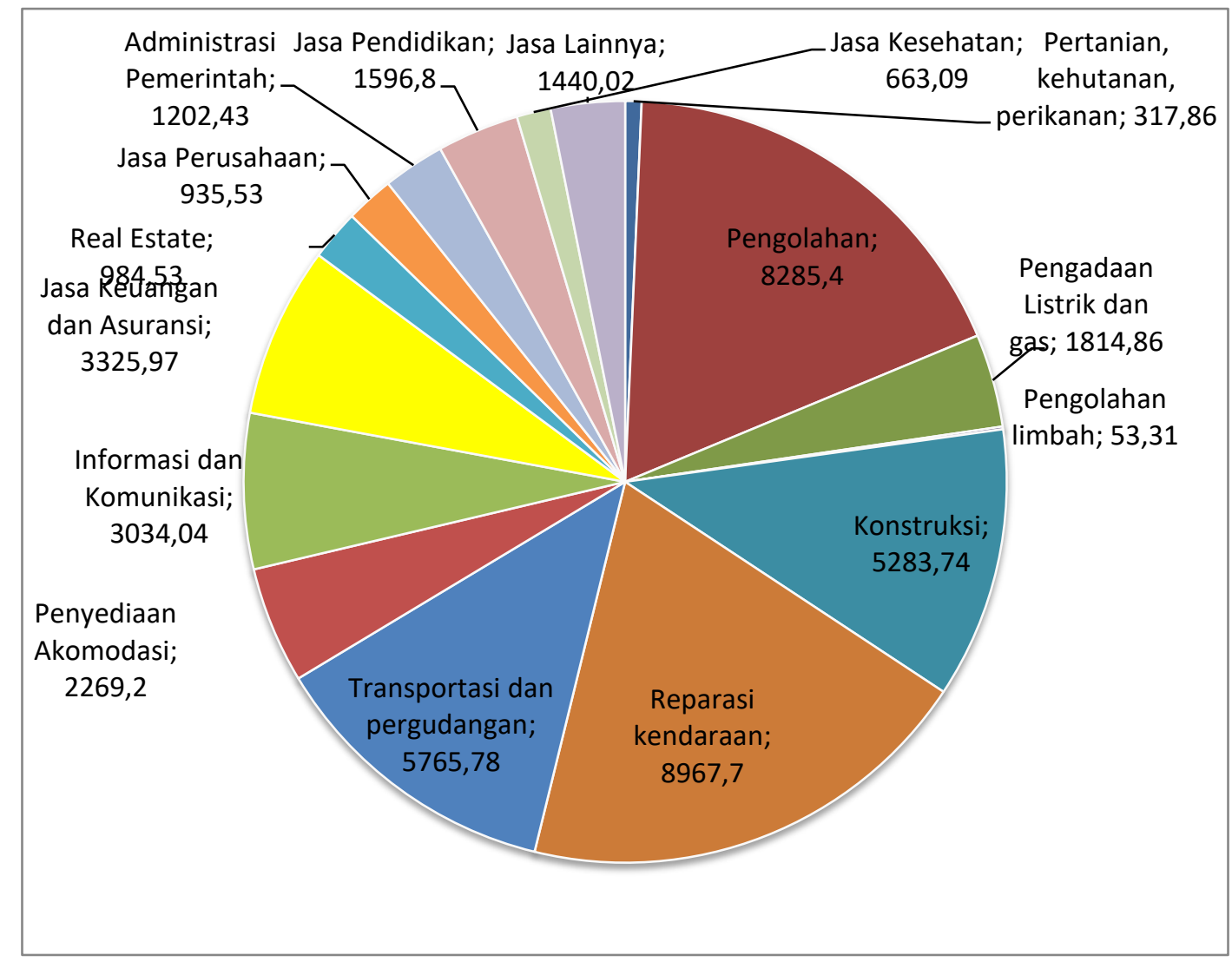

Sumber: BPS (Badan Pusat Statistik) Kota Bogor 2021

Gambar 1. Distribusi PDRB Menurut Lapangan Usaha, tahun 2020

Dari data diagram di atas, masih terbatasnya jumlah industri yang tersebar di wilayah Bogor dimana industri biasanya lahir dari sebuah UMKM, sehingga UMKM diharapkan akan terus tumbuh besar menjadi sebuah industri dan perusahaan, karena menurut peneliti salah satu faktor sedikitnya jumlah perusahaan industri dan UMKM yang ada di Bogor ialah faktor kurangnya UMKM dalam memasarkan produk atau jasanya secara digital atau Online, karena Efektivitas pemasaran Online atau digital pada sebuah UMKM perlu diperhatikan, agar terus mendongkrak penjualan ke arah yang signifikan.

Hal ini diperkuat dalam sebuah riset oleh A. Budiyanto, \& A.A. Effendy, (2020), diantara hambatan perkembangan UMKM ialah "Terbatasnya sarana dan prasarana usaha terutama berhubungan dengan alatalat teknologi. Kebanyakan UMKM menggunakan teknologi yang masih sederhana sehingga sulit untuk bersaing secara kualitas dan kuantitas."

Karena saat ini pada masa era digital, maka sebuah solusi dalam mengembangkan usaha yaitu dengan pemasaran melalui digital atau promosi Online, hal ini 
sebagaimana riset yang dilakukan oleh Effendy, A. A., \& Sunarsi, D. (2020). "Promosi Online lebih efektif pemasarannya melalui Media Sosial yaitu Whatsapp dengan presentase paling tinggi sebesar 34\%, Instagram dengan presentase $31 \%$, facebook dengan presentase $19 \%$ dan selainnya, informan juga menggunakan media sosial berupa twitter sebesar $4 \%$, website sebesar $4 \%$ dan Online shop: shopee sebesar $8 \%$, sehingga promosi sangat efektif dilakukan melalui media Online terutama lebih efektif dilakukan promosinya melalui media sosial dibandingkan promosi melalui media elektronik, dan media cetak."

Hal ini sesuai dengan hasil riset yang dilakukan oleh Fadly, H. D., \& Sutama, S. (2020), "Bahwa pandemi COVID-19 ini telah banyak menimbulkan dampak terhadap pertumbuhan ekonomi yang ada di indonesia, hal ini tentunya akan mempengaruhi roda perekonomian kita. Salah satu kiat yang efektif untuk diterapkan pada masa pandemi ini adalah dengan memaksimalkan pemasaran Online dan membangun branding kita, mengingat semakin banyaknya masyarakat yang memulai WFH (work from home), dengan demikian peluang untuk memaksimalkan pemasaran kita semakin mudah karena penggunaan internet pada saat pandemi Covid-19 meningkat pesat."

Sebagaimana juga riset yang dilakukan oleh Anugrah, R. J. (2020), menurutnya, "Dengan kecenderungan masyarakat yang lebih memilih menghabiskan waktu dengan menggeluti media sosial, perusahaan akan dengan mudah mencapai target yang mereka tentukan."

Oleh karena itu, WPI (Wirausaha Pelajar Indonesia) sebagai wadah para remaja yang berwirausaha baik dari kalangan pelajar maupun mahasiswa, khususnya Kota Bogor, perlu mempelajari secara mendalam mengenai keilmuan berbisnis, agar usaha atau bisnis yang dijalankan dapat mampu bertahan dan berkembang di saat pandemi seperti saat ini. Namun para remaja yang tergabung dalam sebuah wadah atau organisasi seperti WPI (Wirausaha Pelajar Indonesia) perlu juga didukung karena baik organisasi ataupun "Sebuah lembaga, semestinya perlu didukung oleh semua eleman masyarakat, baik guru, orangtua, masyarakat sekitar dan termasuk dosen-dosen diharapkan dapat mengabdi dan berperan serta dalam membentuk untuk mewujudkannya. (Effendy, A. A., et. al (2020).

Maka pada dasarnya usia remaja adalah termasuk usia yang masih perlu terus mengasah kemampuan, belajar dan memperdalam wawasan, maka disarankan di usia remaja, baik pada saat menjadi pelajar maupun mahasiswa, harus terus haus ilmu dan belajar. "Belajar pada hakikatnya adalah 'perubahan' yang terjadi di dalam diri seseorang setelah berakhirnya melakukan aktivitas belajar. walaupun pada kenyataannya tidak semua perubahan termasuk ketegori belajar." (Hamalik, Oemar. 2008 : 37).

Ciri-ciri tertentu dalam kegiatan belajar menurut Edi Suardi dalam (Djamarah, Syaiful Bahri et al, 2014:39-41), diantaranya yaitu "Belajar mengajar memiliki tujuan, yakni untuk membentuk anak didik dalam suatu perkembangan tertentu dan didesain untuk mencapai tujuan yang telah ditetapkan."

\section{METODE}

Metode pendekatan yang digunakan dalam kegiatan PKM ini adalah sebagai berikut:

Saat permulaan dalam pelaksanaan kegiatan, dimulai dengan ice breaking dan brain gym agar peserta PKM dapat lebih termotivasi mengikuti penyuluhan yang diberikan oleh dosen-dosen Fakultas Ekonomi Universitas Pamulang. Sambutan sebagai pembuka dari rangkaian acara oleh Ketua Pelaksana PKM dosen Fakultas Ekonomi Universitas Pamulang dan dari pihak wirausaha pemula yang terdiri dari pelajar dan mahasiswa yaitu Founder WPI Bogor dan Pembina Wirausaha Pelajar Indonesia (WPI) Pusat serta dilanjutkan dengan pembacaan doa sebelum memulai kegiatan agar seluruh rangkaian kegiatan dapat berjalan lancar.

Penyajian materi kegiatan Pemberian Materi PKM dengan tema "Meningkatkan Daya Jual Produk melalui Pemasaran Online di Masa Pandemi pada WPI (Wirausaha Pelajar Indonesia) Wilayah Bogor". Dalam pemberian materi kewirausahaan 
menggunakan video conference berupa Aplikasi Zoom. Setelah Pemberian pelatihan mengenai kewirausahaan kemudian dilanjutkan dengan kuis dan tanya jawab. Rangkaian kegiatan diakhiri dengan pembacaan doa penutup

\section{HASIL DAN PEMBAHASAN}

Permasalahan yang dihadapi oleh Wirausaha Pelajar Indonesia (WPI) Bogor ialah Kurangnya Ilmu pengetahuan dalam wirausaha Wirausaha Pelajar Indonesia (WPI) Bogor belum memiliki ilmu pengetahuan dan wawasan yang memadai mengenai wirausaha yang kreatif, inovatif dan diferensiatif dan Tidak adanya yang membimbing dalam menjalankan bisnis. Wirausaha Pelajar Indonesia (WPI) Bogor tidak ada yang membimbing dalam menjalankan bisnis atau usaha, sehingga mereka ragu dan merasa takut dalam memulai dan menjalankan bisnis.

Solusi yang diusulkan atau ditawarkan dalam kegiatan PKM ini yaitu (1) Pemberian motivasi dan ilmu kewirausahaan. Dalam Pemberian motivasi dan ilmu kewirausahaan kepada Wirausaha Pelajar Indonesia (WPI) Bogor mengenai wirausaha yang kreatif, inovatif dan diferensiatif yaitu produk yang mempunyai ciri khas agar mudah dikenali masyarakat. Keilmuan wirausaha ini tidak hanya sekedar teori namun terdapat motivasi yaitu motivasi yang diberikan berupa kisah Sukses beberapa orang yang

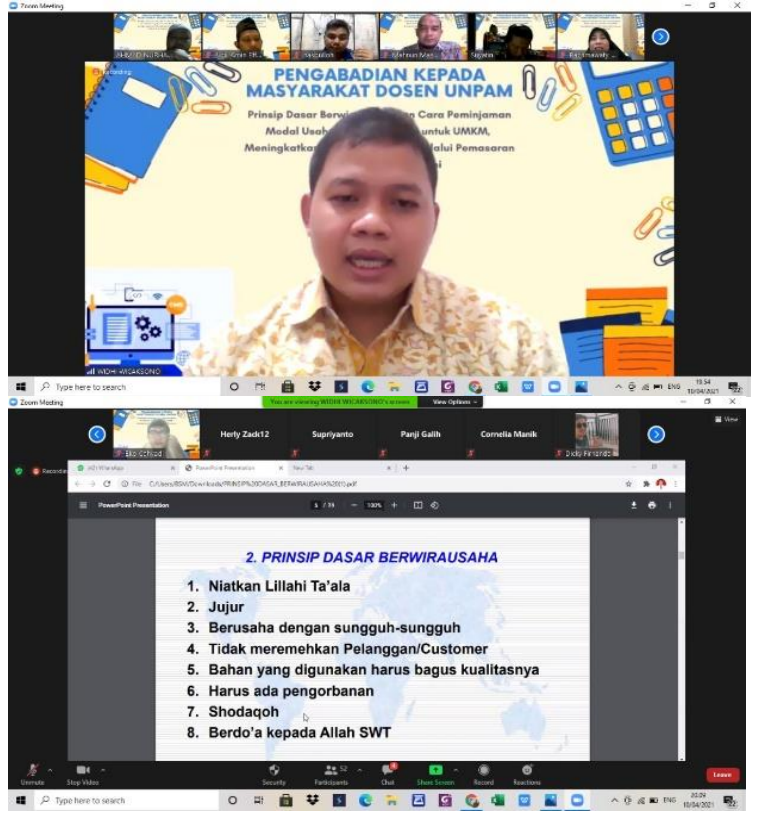

sukses dalam berwirausaha seperti kisah sukses bapak alm. Bob Sadino, ustadz Yusuf Mansur, bapak DR. (HC). H. Darsono sebagai pendiri Unpam dan lain sebagainya, hal ini agar remaja sebagai generasi muda dapat termotivasi dan mengambil pelajaran yang diberikan oleh orang-orang yang sudah menjalankan usaha dan sukses dalam berwirausaha. (2) Bimbingan dalam menjalankan bisnis

Solusi yang diberikan kepada mitra atau Wirausaha Pelajar Indonesia (WPI) Bogor: bimbingan bagaimana cara menjual produk dan kemudian kita membimbing sampai wirausaha pemula yang terdiri dari pelajar dan mahasiswa benar-benar dapat mengembangkan usahanya. Bimbingan ini berupa arahan bagaimana menjadi para pelaku wirausaha yang berhasil dan wawasan mengenai bahan baku yang mudah didapat, cara terbaik pemasaran dan bagaimana produk laku serta bagaimana cara mendapatkan laba yang maksimal. (3) Praktek dan simulasi cara dagang dan bahasa dalam menjual produk. Dosen Unpam sebagai pihak penyelenggara akan mengadakan praktek dan simulasi cara dagang dan bahasa dalam menjual produk, sehingga pihak wirausaha pemula yang terdiri dari pelajar dan mahasiswa dapat langsung belajar mempraktekkan cara menjual produk dengan bahasa yang baik, mudah dipahami konsumen dan produk yang kita jual agar mudah laku di pasaran.
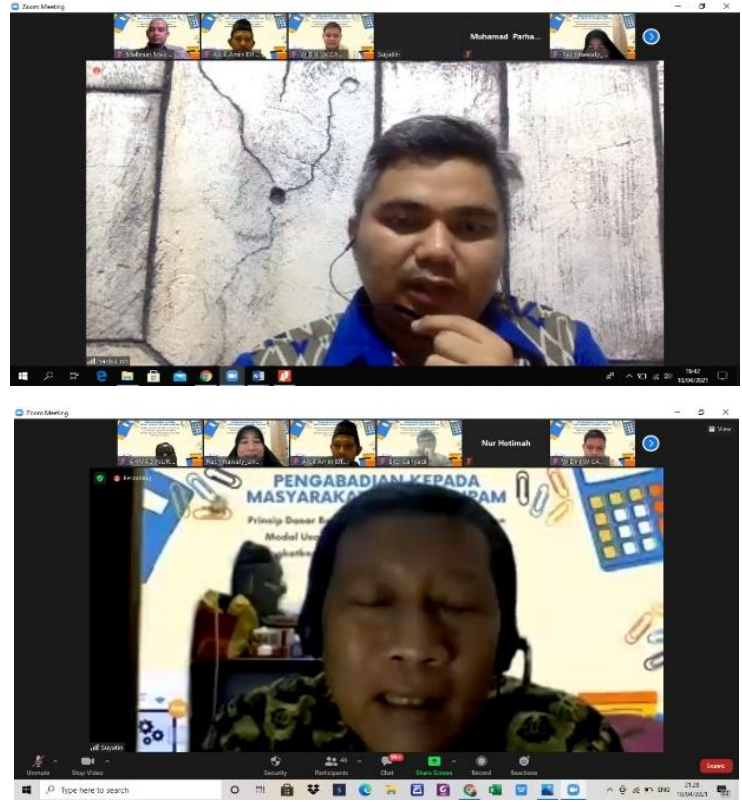

Gambar 2. Kegiatan PKM Melalui Via Online 


\section{PENUTUP}

WPI (Wirausaha Pelajar Indonesia) sebagai wadah para remaja yang berwirausaha baik dari kalangan pelajar maupun mahasiswa, khususnya Kota Bogor, perlu mempelajari secara mendalam mengenai keilmuan berbisnis, agar usaha atau bisnis yang dijalankan dapat mampu bertahan dan berkembang di saat pandemi seperti saat ini. Namun para remaja yang tergabung dalam sebuah wadah atau organisasi seperti WPI (Wirausaha Pelajar Indonesia) perlu juga didukung karena baik organisasi ataupun "Sebuah lembaga, semestinya perlu didukung oleh semua eleman masyarakat, baik guru, orangtua, masyarakat sekitar dan termasuk dosendosen diharapkan dapat mengabdi dan berperan serta dalam membentuk untuk mewujudkannya.

\section{DAFTAR PUSTAKA}

Anugrah, R. J. (2020). "Efektifitas Penerapan Strategi Online Marketing oleh UMKM dalam Masa Pembatasan Sosial Berskala Besar (PSBB) Corona Viruses Disease 2019 (Covid-19)." MANOVA (Jurnal Manajemen dan Inovasi), 2(2).

BPS (Badan Pusat Statistik) Kota Bogor. 2020.

https://bogorkota.bps.go.id/publicatio n.html, diakses pada 29 Maret 2021

Budiyanto, A., \& Effendy, A. A. (2020). Analisa Kebijakan Pemerintah Kota Tangerang Selatan terhadap Pemberdayaan Koperasi dan UMKM dan Dampaknya terhadap Pemerataan
Kesejahteraan Masyarakat. Jurnal Mandiri: Ilmu Pengetahuan, Seni, Dan Teknologi, 4(1), 80-93.

Djamarah, Syaiful Bahri dan Aswan Zain. 2014. Strategi Belajar Mengaja. Cet 5, PT Rineka Cipta, Jakarta. Hlm. 39-41

Effendy, A. A., Budiyanto, A., Nurhadi, A., Murtiyoko, H., \& Mas'adi, M. (2020). "Implementasi Kewirausahaan dan Koperasi di Sekolah pada SMK Mulia Buana, Parung Panjang-Kab. Bogor." DEDIKASI PKM, 1(2), 105-110.

Effendy, A. A., \& Sunarsi, D. (2020). Persepsi Mahasiswa Terhadap Kemampuan Dalam Mendirikan UMKM Dan Efektivitas Promosi Melalui Online Di Kota Tangerang Selatan. Jurnal Ilmiah MEA (Manajemen, Ekonomi, \& Akuntansi), 4(3), 702-714.

Fadly, H. D., \& Sutama, S. (2020). "Membangun Pemasaran Online Dan Digital Branding Ditengah Pandemi Covid-19." Jurnal Ecoment Global: Kajian Bisnis dan Manajemen, 5(2), 213-222.

Hamalik, Oemar. 2008. Kurikulum dan Pembelajaran, Cet. 7, PT. Bumi Aksara, Jakarta. Hlm. 37

Nasution, Prof. Dr. S., 2015. “Berbagai Pendekatan dalam Proses Belajar dan Mengajar", PT Bumi Aksara, Jakarta

Rahayu, R., \& Day, J. (2015). Determinant Factors of E-commerce Adoption by SMEs in Developing Country: Evidence from Indonesia. Procedia-Social and Behavioral Sciences, 195, 142-150. 